\title{
БИОАКТИВНЫЕ КРЕМНИЙОРГАНИЧЕСКИЕ ГИДРОГЕЛИ И ИХ ЭЛЕМЕНТ-МОДИФИЦИРОВАННЫЕ ПРОИЗВОДНЫЕ ДЛЯ МЕДИЦИНЫ И ВЕТЕРИНАРИИ
}

\author{
Т.Г. Хонина ${ }^{1,2}$, О.Н. Чупахин ${ }^{1,3}$ \\ ${ }^{1}$ Институт органического синтеза им. И.Я. Постовского Уральского отделения Российской \\ академии наук, 620108, Россия, г. Екатеринбург, ул. С. Ковалевской, д. 22. \\ 2 Уральский государственный аграрный университет, \\ 620075, Россия, г. Екатеринбург, ул. Карла Либкнехта, д. 42. \\ ${ }^{3}$ Химико-технологический институт, Уральский федеральный университет \\ им. Первого президента России Б.Н. Ельцина, \\ 620002, Россия, г. Екатеринбург, ул. Мира, д. 19.
}

DOI: 10.19163/MedChemRussia2021-2021-19

E-mail:khonina@ios.uran.ru

В Институте органического синтеза им.И.Я. Постовского УрО РАН был синтезирован с использованием золь-гель метода целый ряд фармакологически активных элементсодержащих гидрогелей, в том числе, нанокомпозитных, на основе полиолатов кремния, титана, цинка, борав качестве биосовместимых прекурсоров [1-5]. Были установлены общие закономерности и выявлены особенности зольгель процесса для каждого типа прекурсоров.

Синтезированные гели могут быть использованы как самостоятельные лекарственные средства с широким спектром фармакологической активности для местного и наружного применения, так и в качестве основ фармацевтических композиций, обеспечивающих эффективную доставку лекарственных субстанций в пораженные органы и ткани.

В докладе приведены многочисленные примеры использованиягеля на основе глицеролатов кремния («Силативит») и его элемент-модифицированных производных в лечении воспалительных стоматологических и ряда других заболеваний (слизистой оболочки, кожи, мягких тканей, суставов), а также в лечении заболеваниймолочной железы, органов репродуктивной системы и копытец у сельскохозяйственных животных.

Работа выполнена в соответствии с планами НИР и государственным заданием на 2021 г. (государственная регистрация № АAAA-A19-119011790134-1).

\section{Литература}

[1] T.G.Khonina, A.P.Safronov, M.V. Ivanenko et al., Journal of Materials Chemistry B. 2015.3, 5490-5500.

[2] T.G.Khonina, M.V. Ivanenko, O.N. Chupakhinet al., European Journal of Pharmaceutical Sciences. 2017. 107, 197-202.

[3] T.G. Khonina, N.V. Kungurov, N.V. Zilberberg et al., Journal of Sol-Gel Science and Technology. 2020. 95, 682-692.

[4] T.G. Khonina, O.N. Chupakhin, V.Ya. Shur et al., Colloids and Surfaces B: Biointerface. 2020. 189, Articlenumber 110851.

[5]Т.Г. Хонина, Е.Ю. Никитина, Е.В. Шадрина и др., Известия Академии наук. Серия химическая. 2021. 70, 967-974. 